\title{
Work-Life Quality, Job Involvement, and Affective Commitment of School Teachers
}

\author{
Burmansah, Bedjo Sujanto, Mukhneri Mukhtar
}

\begin{abstract}
The purpose of this study is to examine the influence of work-life quality and job involvement perceived by teachers to their affective commitment so that they feel a strong emotional bond to their work and school organization, are able to identify the goals and values of the school organization well, and really want to be there. This research uses causal survey method by using path analysis technique. This study uses the sample from 138 teachers in eight buddhist senior high schools in Jakarta, which were selected using the Slovin formula. The result of the study reveals that first, there is a positive effect between the quality of work life and the affective commitment of the teachers in school. Second, there is a positive effect between job involvement and affective commitment of teachers in school. Third, there is a positive effect between quality of work life and job involvement teachers in school.
\end{abstract}

Keywords: affective commitment; schoolteacher; work-life quality; Slovin formula; job involvement

\section{INTRODUCTION}

It is a fact that affective commitment (AC) is more likely to be an indicator of how teachers want to stay at school because they want to, they are satisfied with the school, they identify with the school, and they strive for the school's success. They and the school are satisfied with the work they do at school (1). AC refers to emotional connection, identification, and involvement in organization (2). The emotional connection between employees and their organization or their AC has been regarded as an important determiner of dedication and loyalty (3). The factors which make someone stay with their organization today are emotional reasons, including those related to friendship, the work atmosphere or culture, and comfortability in completing tasks. These are a few emotional reasons which can induce AC (4). In this case, the situation and condition of the work place influences the increase of $\mathrm{AC}$ of a teacher (5). For example, a teacher has a high AC towards the profession of a teacher, but they have a low AC towards the working group and the school where they work. Even though the teacher enjoys this profession, they have some difficulty in terms of their working group and school (6). Another problem which possibly influences $\mathrm{AC}$ based on previous research suggests that the AC of employees is directly and positively influenced by the issue of the work-life quality (WLQ) and the job involvement (JI) of the employees. In

Revised Manuscript Received on September 22, 2019.

Burmansah, Postgraduate Student, Universitas Negeri Jakarta, Indonesia. burmansah_mp16s3@mahasiswa.unj.ac.id

Bedjo Sujanto, Professor, Universitas Negeri Jakarta, Indonesia

Mukhneri Mukhtar, Professor, Universitas Negeri Jakarta, Indonesia. fact, the WLQ affects the JI, and, in the end, influences the $\mathrm{AC}$ in an employee $(7,8)$.

\section{A. Objectives of the Study}

The aim of this research is to obtain correct and reliable comprehension regarding the work-life quality (WLQ) and job involvement (JI) towards affective commitment (AC). This study is conducted to know:

- The direct and positive influence of the WLQ towards the AC of the Buddhist School' teachers.

- The direct and positive influence of the JI towards the AC of the Buddhist School' teachers.

- The direct and positive influence of the WLQ towards the JI of the Buddhist School' teachers.

\section{B. Hypothesis of the Study}

Based on the existing literature regarding this research, the hypothesis is as follows:

- H-1: There is a direct and positive influence of the WLQ towards the AC of the Buddhist School' teachers.

- H-2: There is a direct and positive influence of the JI towards the AC of the Buddhist School' teachers.

- H-3: There is a direct and positive influence of the WLQ towards the JI of the Buddhist School' teachers.

\section{LiteratuRE REVIEW}

\section{A. Affective Commitment (AC)}

$\mathrm{AC}$ is defined as positive emotional state in which the employee is willing to make an effort and choose to stay with the organization and to continue being a member of the organization because of emotional connection, organizational involvement, and faith in the values $(4,9,10)$. AC refers to the strength of people's willingness to continue working at an organization because they regard it positively and they agree with the goals and values it stands for (11). $\mathrm{AC}$ involves the emotional proximity of the employees, identification, and the involvement in the organization $(12,13)$.

\section{B. Work-Life Quality (WLQ)}

WLQ is a management philosophy which increases the dignity of the employees, introduces the culture change, gives chance for growth and development, increases the dignity of all the employees, introduces changes within the organization, how far they work, and membership in the organization when it 
facilitates the personal needs and interests which are required through their experience in the organization (14-17). WLQ is an opinion and impression based on the work conditions of employees in an organization (18). The WLQ refers to the perception of the employee's welfare physically and psychologically in the work place (19). The WLQ is about the work environment, rewards, commitment towards the organization, acknowledgement, participative management, work-life balance, welfare facilities, proper complaint management, work satisfaction, etc. (20).

\section{Job Involvement (JI)}

JI is how far someone identifies and dedicates him or herself towards his or her job, having faith that there is a connection between individual performance in work and his or her dignity, active participation within, and regarding work performance as important (21-23). JI is how far someone personally involves him or herself in his or her job role (24). JI is the internalization of the values of righteousness about work or the importance of a job in individual values. JI is related with the importance of a job in someone's daily life or routine. This means that if one gives the importance of his or her work, he or she would be loyal toward his or her job and organization. This also affects the performance of an individual (25).

\section{Methodology/Materials}

\section{A. Research Approach}

This research uses the quantitative-causal approach as the method of survey research. In this research, the WLQ is an exogenous variable, $\mathrm{JI}$ is an intervening endogen variable, and $\mathrm{AC}$ is a final endogen variable.

\section{B. Participants}

This research was conducted in Buddhist Schools in Jakarta. The analysis unit in this research is the Buddhist School's teachers in Jakarta. The population is all the Buddhist School's teachers which live in Jakarta with a total of 211 teachers out of 8 schools, ignoring the sex and education background. The samples were selected with the simple random sampling method by choosing the members of the population randomly, ignoring the classes (levels) of each of the population members. The population is homogenous and has a large number. From the existing population, the number of samples were calculated with the Slovin formula. Therefore, the sample used in this research is 138 teachers.

\section{Data Collection}

To obtain data in this research, a questionnaire was used for the three variables: WLQ (X1), JI (X2), and AC (Y). All the questionnaires were filled in by teachers from Buddhist High Schools in Jakarta. All the research instruments has tested and analyzed by the validity test and all the instruments had high reliability. Thus, all the instruments could be used in the research to obtain data.

\section{Data Analysis}

This research aims to know the influence of WLQ and JI towards the teacher's AC. The analysis technique used is the path analysis.

\section{RESUlts AND FINDINGS}

\section{A. Data Description}

\section{1) Affective Commitment (AC)}

The data obtained from the field was processed statistically into a table of frequency distribution. The number of classes were calculated according to Sturges' rules. The results show eight classes with a maximum score of 148 and minimum score of 109. Therefore, the range of score is 39 . The results of the descriptive statistic calculation show that average value (mean) of the AC is 126,93 with a standard deviation of 7,19 and a variant value of 51,6881, median of 126,52, and modus of 126,99.

\section{2) Work-Life Quality (WLQ)}

The WLQ data has a theoretic score range of 33 to 165 and an empiric score range of 102 to 165 . Therefore, the range of score is 63 . The data calculation results show an average value of 129,78 , standard deviation of 12,67 , variant of 160,6426 , median of 130,00 , and modus of 134,42 .

\section{3) Job Involvement (JI)}

The JI data has a theoretic score range of 32 to 160 and an empiric score range of 103 to 158 . Therefore, the score range is 55. The results from the data calculation show an average of 127,98 , standard deviation of 11,83 , variant of 139,8608 , median of 127,97 , and modus of 128,17 .

\section{B. Test of Analytic Requirements}

\section{1) Normality Test}

The normality test was done using the Liliefors technique. The $\mathrm{H} 0$ criteria which states that the scores do not have a normal distribution is that if Lcount is less than Ltable. The results show that $\mathrm{IF}(\mathrm{Zi})-\mathrm{S}(\mathrm{Zi}) \mathrm{I}$ is maximum which is concluded by Lcount for the three estimated errors of regression which are less than Ltabel. The rejected limit for $\mathrm{H} 0$ which is shown in the Liliefors table for $\alpha=0,05$ and $n>30$ is $\frac{0,886}{\sqrt{n}}$. The results of the normality test are as follows:

\section{a) Normality Test for Estimated Errors of Regression of $\mathrm{Y}$ over $\mathrm{X}_{1}$}

The results show that $\mathrm{L}_{\text {count }}=0,0521$. This value is less than $\mathrm{L}_{\text {table }}(\mathrm{n}=138 ; \alpha=0,05)$ which is 0,075 . The distribution of data for AC over WLQ forms a normal curve.

\section{b) Normality Test for Estimated Errors of Regression of $\mathrm{Y}$ over $\mathrm{X}_{2}$}

The results show that $\mathrm{L}_{\text {count }}=0,0290$. This value is less than $\mathrm{L}_{\text {table }}(\mathrm{n}=138 ; \alpha=0,05)$ which is 0,075 . The distribution of data for $\mathrm{AC}$ over JI forms a normal curve.

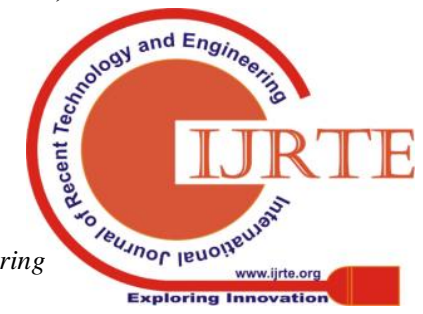




\section{Normality Test for Estimated Errors of Regression of $\mathrm{X}_{2}$ over $\mathrm{X}_{1}$}

The results show that $\mathrm{L}_{\text {count }}=0,0521$. This value is less than $\mathrm{L}_{\text {table }}(\mathrm{n}=138 ; \alpha=0,05)$ which is 0,075 . The distribution of data for JI over WLQ forms a normal curve.

\section{2) Significance and Linearity of Regression Test}

\section{a) Test of the Significance and Linearity of the Regression Model for AC over WLQ}

The results of the calculation for the regression model between AC and WLQ shows that the regression constant $\mathrm{a}=$ 96,62 and the regression coefficient $b=0,23$. Therefore, the relationship of the simple regression model is $\hat{X}_{3}=96,62+$ $0,23 \mathrm{X}_{1}$.

The regression model $\hat{X}_{3}=96,62+0,23 X_{1}$ for the significance test shows that $F_{\text {count }} 27,76$ is more than $F_{\text {table }}$ ${ }_{(0,01 ; 1: 136)} 6,82$ for $\alpha=0,01$. Because $F_{\text {count }}>F_{\text {table }}$, the regression is very significant. The linearity test shows that $\mathrm{F}_{\text {count }}$ is 0.96 which is less than $\mathrm{F}_{\text {table }(0,05 ; 41: 95)}$ which is 1.52 for $\alpha=0.05$. Because $F_{\text {count }}<F_{\text {table, }}$, the distributions of dots which are estimated to form a linear line can be accepted.

\section{b) Test of the Significance and Linearity of the Regression Model for AC over JI}

The results of the calculation for the regression model between $\mathrm{AC}$ and JI shows that the regression constant $\mathrm{a}=$ 95,76 and regression coefficient $b=0,24$. Therefore, the relationship of the simple regression model is $\hat{X}_{3}=95,76+$ $0,24 \mathrm{X}_{2}$.

The regression model $\hat{X}_{3}=95,76+0,24 X_{2}$ for the significance test shows that $F_{\text {count }} 26,00$ is more than $F_{\text {table }}$ $(0,01 ; 1: 136) 6,82$ for $\alpha=0,01$. Because $F_{\text {count }}>F_{\text {table }}$, the regression is very significant. The linearity test shows that $F_{\text {count }}$ is 1,13 which is less than $F_{\text {table }}(0,05 ; 45: 91)$ which is 1,51 for $\alpha=0,05$. Because $F_{\text {count }}<F_{\text {table, }}$, the distributions of dots which are estimated to form a linear line can be accepted.

\section{c) Test of the Significance and Linearity of the Regression Model for JI over WLQ}

The results of the calculation for the regression model between JI and WLQ shows that the regression constant $\mathrm{a}=$ 96,05 and regression coefficient $b=0,25$. Therefore, the relationship of the simple regression model is $\hat{X}_{2}=96,05+$ $0,25 \mathrm{X}_{1}$.

The regression model $\hat{X}_{2}=96,05+0,25 \mathrm{X}_{1}$ for the significance test shows that $F_{\text {count }} 10,16$ is more than $F_{\text {tabel }}$ $(0,01 ; 1: 136) 6,82$ for $\alpha=0,01$. Because $F_{\text {count }}>F_{\text {table }}$, the regression is very significant. The linearity test shows that $F_{\text {count }}$ is 1,06 which is less than $F_{\text {tabel }(0,05 ; 41: 95)}$ which is 1,52 for $\alpha=0,05$. Because $F_{\text {count }}<F_{\text {table, }}$ the distributions of dots which are estimated to form a linear line can be accepted.

\section{3) Test of Hypothesis}

Based on the analysis in the previous section and the calculations as shown abovementioned, the summary is as shows that the correlation between WLQ and JI is 0,264 . The correlation between WLQ and AC is 0,412 . The correlation between $\mathrm{JI}$ and $\mathrm{AC}$ is 0,401 .

\section{a) First Hypothesis}

The WLQ has a direct and positive influence towards AC. $\mathrm{H}_{0}: \beta_{31} \leq 0$

$\mathrm{H}_{1}: \beta_{31}>0$

$\mathrm{H}_{0}$ is rejected if $\mathrm{t}_{\text {count }}>\mathrm{t}_{\text {table }}$.

Based on the calculations from the path analysis, the direct influence of WLQ towards AC, the coefficient value is 0,329 and $t_{\text {count }}$ is 4,29 . The value of $t_{\text {table }}$ for $\alpha=0,01$ is 2,61 . Therefore, because the value of $t_{\text {count }}$ is more than the value of $t_{\text {table, }} \mathrm{H}_{0}$ is rejected and $\mathrm{H}_{1}$ is accepted. In other words, WLQ has a direct influence towards AC.

The analysis of the first hypothesis shows that WLQ has a direct and positive influence towards AC. Thus, it can be concluded that $\mathrm{AC}$ is influenced directly and positively by WLQ. An increase in WLQ causes an increase in AC.

\section{b) Second Hypothesis}

$\mathrm{JI}$ has a direct and positive influence towards AC.

$\mathrm{H}_{0}: \beta_{32} \leq 0$

$\mathrm{H}_{1}: \beta_{32}>0$

$\mathrm{H}_{0}$ is rejected if $\mathrm{t}_{\text {count }}>\mathrm{t}_{\text {table. }}$.

Based on the calculations from the path analysis, the direct influence of JI towards AC, the coefficient value is 0,314 and $t_{\text {count }}$ is 4,10 . The value of $t_{\text {table }}$ for $\alpha=0,01$ is 2,61 . Therefore, because the value of $t_{\text {count }}$ is more than the value of $t_{\text {table, }} H_{0}$ is rejected and $H_{1}$ is accepted. In other words, it can be accepted that JI has a direct influence towards AC.

The analysis of the second hypothesis shows that JI has a direct and positive influence towards AC. Based on that finding, it can be concluded that AC is influenced directly and positively by JI. An increase in JI causes an increase in $\mathrm{AC}$.

\section{c) Third Hypothesis}

WLQ has a direct and positive influence towards JI.

$\mathrm{H}_{0}: \beta_{21} \leq 0$

$\mathrm{H}_{1}: \beta_{21}>0$

$\mathrm{H}_{0}$ is rejected if $\mathrm{t}_{\text {count }}>\mathrm{t}_{\text {table }}$.

Based on the calculations from the path analysis, the direct influence of WLQ towards JI, the coefficient value is 0,264 and $t_{\text {count }}$ is 3,19 . The value of $t_{\text {table }}$ for $\alpha=0,01$ is 2,61 . Therefore, because the value of $t_{\text {count }}$ is more than the value of $t_{\text {table, }} H_{0}$ is rejected and $H_{1}$ is accepted. In other words, it can be accepted that WLQ has a direct influence towards JI. The analysis of the third hypothesis shows that WLQ has a direct and positive influence towards JI. Therefore, it can be concluded that JI is influenced directly and positively by WLQ. An increase in WLQ causes an increase in JI.

\section{4) Discussion of Research Results}

Based on the literature review and empirical study above, the research results are

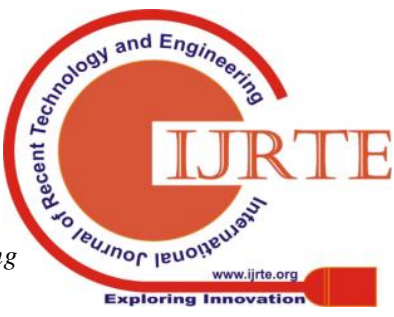


discussed below to conduct a synthesis between the theory and the empirical findings. The detailed discussion of the analysis and hypothesis tests are elaborated below:

\section{a) The Influence of WLQ towards AC}

The first hypothesis test concludes that there is a direct and positive influence of WLQ towards AC with a correlation coefficient of 0,412 and path coefficient value of 0,329 . This means that WLQ has a direct influence towards AC. Previous research findings show that there is a significant positive influence of WLQ towards AC (12,26-28). WLQ is able to positively influence AC and increase their loyalty, which reduces turnover in an organization (29-31). In addition, increasing the WLQ in an organization makes employees more committed, motivated, and productive (32). A perfect WLQ will help an organization. An increase in the WLQ will improve employee welfare and, in turn, the welfare of the whole organization. This is an effort to take advantage of human resources in an organization (33). The WLQ of teachers integrate work roles and social roles so that they synergize effectively (34). If teachers increase WLQ and the work culture of a school, it will be beneficial towards the function of an educational organization effectively and individually (35). Teachers with high JI strongly favor their type of work and really care about increasing the quality of the school, happily obey the school rules and support school policies, etc. This research concludes that WLQ has a direct and positive relationship towards AC. This means that optimal WLQ increases Buddhist School teachers' AC.

\section{b) The Influence of JI towards AC}

The second hypothesis test concludes that there is a direct and positive influence of JI towards AC with a correlation coefficient of 0,401 and a path coefficient value of 0,314 . This means that JI directly influences AC. Previous research similarly concludes that employees' high JI will make employees have a deep emotional attachment (AC) to stay in the organization (36-38). People who are not involved in their jobs and who think that their jobs are not an important aspect of their life, psychologically, what can occur is dissatisfaction with their superior as a whole, and it results in low AC in employees (22). JI is indeed important for employee commitment. This clearly shows that organizations who have a culture of JI have more committed employees in comparison to those who do not involve their employees at all (25). Employees who feel a positive change in their daily work experience have AC that can be maintained or even increased $(39,40)$. This research concludes that JI directly and positively influences AC. This means that optimal JI increases Buddhist School teachers' AC.

\section{c) The Influence of WLQ towards JI}

The third hypothesis test concludes that there is a direct and positive influence of WLQ towards JI with a correlation coefficient of 0,264 and a path coefficient value of 0,264 .
This means that the WLQ directly influences JI. This is similar to previous research which state that WLQ greatly influences someone's JI in an organization $(41,42)$. WLQ and all the dimensions in it significantly influence employees' JI (43). WLQ increases confidence, productivity, JI, retention, and problem solving which can increase both employee satisfaction and an organization's effectiveness (15). WLQ in an organization is indeed a difficult task even though there is a collective agreement about the welfare of employees. Factors on work placement and policies influence the work process and psychology of employees (44). WLQ is intended to increase employees' confidence, JI, and problem solving skills which in turn could increase both employee satisfaction and an organization's effectiveness $(14,45)$. This research concludes that WLQ directly and positively influences JI. This means that optimal WLQ increases Buddhist School teachers' JI.

\section{Conclusions}

Based on the results of the research data and the analysis of the data which has been discussed with all the requirements of data analysis, the conclusions derived are as follows:

- WLQ has a direct and positive influence on AC. This means that an increase in WLQ causes an increase in the AC of Buddhist School' teachers.

- JI has a direct and positive influence on AC. This means that an increase in JI causes an increase in the AC of Buddhist School' teachers.

- 3. WLQ has a direct and positive influence on JI. This means that an increase in WLQ causes an increase in the JI of Buddhist School' teachers.

\section{A. Implications}

1) Efforts to increase AC through WLQ

Increasing AC can be done by increasing WLQ. This effort can be carried out by various activities: increasing the faith in WLQ, to attract and maintain competent teachers, to improve the performance of a school, to create a safe and healthy work condition, to increase the teachers' abilities, to maintain the balance of work and other aspects of life, to provide sufficient salary and benefits, and to manage the balance of the teachers' work hours.

\section{2) Efforts to increase AC through JI}

Increasing $\mathrm{AC}$ can be done by increasing JI. Therefore, increasing $\mathrm{AC}$ can be carried out through efforts to give teachers a chance to participate in making decisions related to work, to contribute ideas, to have plans regarding the suggestions, and to implement the suggestions.

\section{B. Recommendations}

- The headmaster, as the highest authority and also the role model for the teachers should be able to advise, direct, and increase the sense of responsibility and ownership towards the school and also awareness of the teacher's profession by creating programs on WLQ. 
- The teachers, in regarding their duties as teachers, should have high AC and love for their jobs so that they can feel sincerity towards the profession, responsibility, and ownership which can encourage themselves to do their job.

\section{Limitations and Future Research}

Researchers may regard this study as a reference in future research related to teachers' AC because the scope of this research is limited to the WLQ and JI.

\section{REFERENCES}

[1] Kiral E, Kacar O. The Relationship between Teachers' School Commitment and School Culture. Int Educ Stud [Internet]. 2016 [cited 2019 Apr 22];9(12):90. Available from: https://www.researchgate.net/publication/311086673_The_Relationshi p_between_Teachers'_School_Commitment_and_School_Culture

[2] Kumari N, Afroz N. The Impact of Affective Commitment in Employees Life Satisfaction. Glob J Manag Bus Res Interdiscip [Internet]. 2013;13(7):25-30. Available from: https://globaljournals.org/GJMBR_Volume13/4-The-Impact-of-Affecti ve-Commitment.pdf

[3] Rhoades L, Eisenberger R, Armeli S. Affective Commitment to the Organization: The Contribution of Perceived Organizational Support. J Appl Psychol. 2001;86(5):825-36.

[4] Colquitt JA, LePine JA, Wesson MJ. Organizational Behavior: Improving Performance and Commitment in the Workplace. 4th ed. New York: McGraw-Hill Education; 2013. 640 p.

[5] Akar H. The Relationships between Quality of Work Life, School Alienation, Burnout, Affective Commitment and Organizational Citizenship: A Study on Teachers. Eur J Educ Res. 2018;7(2):169-80.

[6] Karakuş M, Aslan B. Teachers' commitment focuses: A three-dimensioned view. J Manag Dev [Internet]. 2009 [cited 2019 Apr 23];28(5):425-38. Available from: https://www.researchgate.net/publication/200824384_Teachers'_comm itment focuses A three-dimensioned view

[7] Hussain T, Saleem S. Do Employees' Job satisfaction, Involvement and Commitment Mediate Relationship Between Quality of Work Life and Employees' Retention? World Appl Sci J. 2014;30(2):245-52.

[8] Permarupan PY, Al-Mamun A, Saufi RA. Quality of Work Life on Employees Job Involvement and Affective Commitment Between the Public and Private Sector in Malaysia. Asian Soc Sci [Internet]. 2013;9(7):268-78. Available from: http://dx.doi.org/10.5539/ass.v9n7p268

[9] Robbins SP. Organizational Behavior. 14th ed. New Jersey: Pearson; 2011

[10] Newstrom JW. Organizational Behavior. 14th ed. New York:

[11] Greenberg J. Behavior in Organizations. 10th ed. USA: Pearson; 2011.

[12] Bakhshayesh A, Rahimi M, Eftekhari H. A Survey of the Effect of Dimensions of Quality of Work Life on Organizational Commitment Dimensions. Scro Annu Rep J. 2015;3:1-9.

[13] Luthans F. Organizational Behavior: An Evidence-Based Approach. 12th ed. New York: McGraw-Hill; 2011. 594 p.

[14] Ivancevich JM., Konopaske R, Matteson MT. Organizational Behavior and Management. 10th ed. New York: McGraw-Hill; 2008. 672 p.

[15] Gibson JL. Organizations: Behavior, Structure, Processes. New York: MgGraw-Hill; 2012

[16] Griffin RW, Moorhead G. Organizational Behavior: Managing People and Organizations. 11th ed. USA: South-Western College Pub; 2014. $624 \mathrm{p}$.

[17] Wagner JA, Hollenbeck JR. Management of Organizational Behavior. USA: Prentice-Hall; 2002. $816 \mathrm{p}$

[18] Acheampong A, Muhammed MA, Agyapong K. Perceived Quality of Work Life and Work Performance among University Academic Staff. Int J Curr Res Acad Rev [Internet]. 2016 [cited 2019 Apr 25];4(4):1-13. Available

from: ty_of_Work_Life_and_Work_Performance_among_University_Acade mic_Staff

[19] Cascio WF. Managing Human Resources: Productivity, Quality of Work Life, Profits. 7th ed. New York: McGraw-Hill Irwin; 2006

[20] Ishak SID, Abd Razak N, Hussin H, Fhiri NS, Ishak AS. A Literature Review on Quality Teacher's Working Life. In: MATEC Web of Conferences [Internet]. EDP Sciences; 2018. p. 05094. Available from: https://www.researchgate.net/publication/323359689_A_Literature_Re view_on_Quality_Teacher's_Working_Life McGraw-Hill; 2015. https://www.researchgate.net/publication/301581716_Perceived_Quali

[21] Andre R. Organizational Behavior: An Introduction to Your Live in Organizations. 1st ed. USA: Pearson Prentice Hall; 2008. 608 p.

[22] Noe R, Hollenbeck J, Gerhar B, Wright P. Fundamentals of Human Resource Management. 5th ed. New York: McGraw-Hill Irwin; 2014. $570 \mathrm{p}$.

[23] Schermerhorn Jr. JR, Hunt, Osborn RN, Uhl-Bien M. Organizational Behavior: International Student Version. 12th ed. Asia: John Willey \& Sons, Ltd.; 2012. 648 p.

[24] Kreitner R, Kinicki A. Organizational Behavior. New York: Tata McGraw-Hill; 2008

[25] Iqbal Khan T, Ahmed Jam F, Akbar A, Bashir Khan M, Tahir Hijazi S Job Involvement as Predictor of Employee Commitment: Evidence from Pakistan. Int J Bus Manag [Internet]. 2011;6(4):252-62. Available from:

http://www.ccsenet.org/journal/index.php/ijbm/article/view/10093

[26] Khan MA. Influence of Quality of Work Life on Organizational Commitment Among Clerical-Staff. Asia Pacific J Res. 2015;I(XXV):106-13.

[27] Ali A, SufiyanZilli A. Influence of Quality of Work Life and Job Attitude on Affective Commitment: A Study of Managerial Personnel. Artha - J Soc Sci. 2013;12(1):67-81.

[28] Gupta B, Gupta S. A Study of Impact of Quality of Worklife on Organizational Commitment in Manufacturing Sector. Int J Res Manag Sci Technol. 2013;I(III):301-10.

[29] Zhao X, Sun T, Cao Q, Li C, Duan X, Fan L, et al. The impact of quality of work life on job embeddedness and affective commitment and their co-effect on turnover intention of nurses. $J$ Clin Nurs 2013;22(5-6):780-8.

[30] Eren H, Hisar F. Quality of work life perceived by nurses and their organizational commitment level. Int $\mathbf{J}$ Hum Sci [Internet]. 2016;13(1):1123-1123. Available from: https://www.researchgate.net/publication/303842384_Quality_of_wor k_life_perceived_by_nurses_and_their_organizational_commitment_le vel

[31] Temesgen Y. Teachers' Perception of Their Quality of Work Life and Its Effect on Affective Commitment (A Study of Governmental Schools in Lalibela Town). Res Humanit Soc Sci [Internet]. 2017 [cited 2019 Apr 27];7(21):21-28-28. Available from: https://www.iiste.org/Journals/index.php/EJBM/article/view/39593/407 11

[32] Zain AYM, Mintawati H, Minai MS. Quality of Work Life and Affective Commitment: A Study of Blue-Collar Employees in Northern Malaysia Int J Innov Res Dev [Internet]. 2018 [cited 2019 Apr 22];7(8):7-14. Available from: https://www.researchgate.net/publication/327473814_Quality_of_Wor k_Life_and_Affective_Commitment_A_Study_of_Blue-Collar_Emplo yees_in_Northern_Malaysia

[33] Hannon J, Hung I-C, Lin C. The Mediating Effects of Organization Commitment and Job Involvement on the Relationship Between Quality of Work Life and Customer Service Attitudes. Purdue Univ Press Journals [Internet]. 1994 [cited 2019 Mar 17];1-47. Available from: https://docs.lib.purdue.edu/ciberwp/96/

[34] Bharathi PS, Umaselvi M, Kumar NS. Quality of Work Life: Perception of College Teachers. Indian J Commer Manag Stud [Internet]. 2011 [cited 2018 Dec 20];II(1). Available from: https://www.researchgate.net/publication/48376178\%0AQuality

[35] Manju ND. Quality of Work Life: Perception of School Teachers. Int J Educ Psychol Res [Internet]. 2014 [cited 2018 Dec 2];3(2):77-80. Available from: http://ijepr.org/doc/V3_Is2_June14/ij16.pdf

[36] Rahati A, Sotudeh-Arani H, Adib-Hajbaghery M, Rostami M. Job Involvement and Organizational Commitment of Employees of Prehospital Emergency Medical System. Nurs Midwifery Stud [Internet] 2015;4(4):1-6. Available from: https://www.ncbi.nlm.nih.gov/pmc/articles/PMC4733505/

[37] Bahjat Abdallah A, Yousef Obeidat B, Osama Aqqad N, Khalil Al Janini MN, Dahiyat SE. An Integrated Model of Job Involvement, Job Satisfaction and Organizational Commitment: A Structural Analysis in Jordan's Banking Sector. Commun Netw [Internet] 2017;09(01):28-53. Available from: http://www.scirp.org/journal/doi.aspx?DOI=10.4236/cn.2017.91002

[38] Ajay S, Bindu G. Job involvement, organizational commitment, professional commitment, and team commitment: A study of generational diversity. Benchmarking an Int $\mathrm{J}$ [Internet] 2015;22(6):1192-211. Available from: https://www.researchgate.net/publication/282132109_Singh_Ajay_Gu pta_Bindu_2015_Job_Involvement_Organizational_Commitment_Prof 
essional_Commitment_and_Team_Commitment_-A_Study_of_Genera tional_Diversity_Benchmarking_An_International_Journal_Vol_22_N o7_Em

[39] Lee J, Corbett JM. The impact of downsizing on employees' affective commitment. J Manag Psychol. 2006;21(3):176-99.

[40] El Badawy TA, Chinta R, Magdy MM. Does 'gender' mediate or moderate the relationship between 'quality of work life' and 'organizational commitment'? Evidence from SMEs in Egypt. Gend Manag An Int J. 2018;33(4):332-48.

[41] Salem SMW, Abu Jarad OMN. Impact of Quality of the Work Life on Job Involvement in the Institutions of the Palestinian Public Sector. Am J Bus Manag. 2015;4(3):123-32.

[42] Gupta A. Quality of Working Life and Organizational Development. Open Access Sci Reports J [Internet]. 2013;2(3):2-5. Available from: http://dx.doi.org/10.4172/scientificreports687

[43] Treshalin S, Andrew A. The Impact of Quality of Work Life on Job Involvement of Auto Mechanic Employees. Int J Res [Internet]. 2017 [cited 2019 Apr 26];4(8):1294-309. Available from: https://www.researchgate.net/publication/319645156_The_Impact_of Quality_of_Work_Life_on_Job_Involvement_of_Auto_Mechanic_Em ployees

[44] Srivastava S, Kanpur R. A Study on Quality Of Work Life: Key Elements \& It's Implications. IOSR J Bus Manag. 2014;16(3):54-9.

[45] Werther J, William B, Davis K. Human Resources and Personnel Management. 3rd ed. Singapore: McGraw-Hill Inc; 1989.

\section{AUTHORS PROFILE}

Burmansah, wright know i am Postgraduate Student, Universitas Negeri Jakarta, Indonesia. my area of interest is teaching and learning and for further details contact me. burmansah_mp16s3@mahasiswa.unj.ac.id

Bedjo Sujanto, currently i am Professor, Universitas Negeri Jakarta, Indonesia. my area of interest is learning and teaching.

My good name is Mukhneri Mukhtar, and i am Professor, in Universitas Negeri Jakarta, Indonesia. my area of interest is enhancing knowledge and learning. 